\title{
Proteases with caspase 3-like activity participate in cell death during stress-induced microspore embryogenesis of Brassica napus
}

\author{
Eduardo Berenguer ${ }^{1}$, María-Teresa Solís ${ }^{1,2}$, Yolanda Pérez-Pérez ${ }^{1}$ and Pilar S. Testillano ${ }^{1 \star}$
}

\begin{abstract}
Microspore embryogenesis is a model system of plant cell reprogramming, totipotency acquisition, stress response and embryogenesis initiation. This in vitro system constitutes an important biotechnological tool for haploid and doubled-haploid plant production, very useful for crop breeding. In this process, microspores (cells that produce pollen grains in planta) are reprogrammed toward embryogenesis by specific stress treatment, but many microspores die after the stress. The occurrence of cell death is a serious limiting problem that greatly reduces microspore embryogenesis yield. In animals, increasing evidence has revealed caspase proteolytic activities as essential executioners of programmed cell death (PCD) processes, however, less is known in plants. Although plant genomes do not contain caspase homologues, caspase-like proteolytic activities have been detected in many plant PCD processes. In the present study, we have analysed caspase 3-like activity and its involvement in stress-induced cell death during initial stages of microspore embryogenesis of Brassica napus. After stress treatment to induce embryogenesis, isolated microspore cultures showed high levels of cell death and caspase 3-like proteolytic activity was induced. Treatments with specific inhibitor of caspase 3-like activity reduced cell death and increased embryogenesis induction efficiency. Our findings indicate the involvement of proteases with caspase 3-like activity in the initiation and/or execution of cell death at early microspore embryogenesis in $B$. napus, giving new insights into the pathways of stress-induced cell death in plants and opening a new way to improve in vitro embryogenesis efficiency by using chemical modulators of cell death proteases.
\end{abstract}

Keywords: Cell death, caspase 3-like activity, microspore embryogenesis, stress treatment

'Pollen Biotechnology of Crop Plants laboratory, Biological Research Center, CIBCSIC, Madrid, Spain.

${ }^{2}$ Dep. of Genetics, Physiology and Microbiology, UCM, Madrid, Spain

${ }^{*}$ Corresponding author: P. S. Testillano E-mail: testillano@cib.csic.es

DOI: 10.2478/ebtj-2019-0018
(C) 2019 Authors. This work was licensed under the Creative Commons AttributionNonCommercial-NoDerivs 4.0 License.

\section{Introduction}

Microspore embryogenesis is one of the major in vitro systems to study totipotency and cellular reprogramming into an embryogenic cell, a process that shows the high level of developmental plasticity of plant kingdom. The importance of this in vitro process is the fact that the resulting haploid or doubled-haploid (DH) embryo and plant can be used to shorten breeding programmes for production of new crop varieties, with improved agronomic features (1). The production of $\mathrm{DH}$ plants from microspores is an important technique for developing homozygous lines rapidly (in only one generation), plants that are used as parental lines for hybrid production to generate new isogenic lines for breeding $(2,3)$. In addition, the ability to regenerate complete embryos from other cells than the zygote has been largely exploited as a biotechnological tool for plant propagation and genetic resources preservation $(2,4)$. Since 1964, microspore embryogenesis has been developed for more than 250 species (1), among them, two dicot plants (Brassica napus and Nicotiana tabacum) and two monocot plants (Hordeum vulgare and Triticum aestivum) are model plants for studying the cellular and molecular basis of microspore embryogenesis. However, there are still numerous species with agronomic relevance (i.e. Solanum lycopersicum and Gossypium arborerum) or with significant scientific interest (Arabidopsis thaliana) that have inefficient or recalcitrant responses to this process. 
For the vast majority of inducible species, including B. napus, the most responsive stage for its cellular reprogramming can only be achieved in a narrow time frame before the first mitotic division of the vacuolated microspore $(1,5,6)$. Besides its developmental stage, efficient induction and initiation of microspore embryogenesis depends on multiple factors, such as genotype, donor plants, growth conditions, culture media and type of inductor stress applied (1). One of the principal requirement to enhance reprogramming of plant microspores towards in vitro embryogenesis and to acquire totipotency is the external stress applied, which usually is temperature, osmotic or starvation stress, in many plant species (7). In B. napus, efficient embryogenesis is induced by high temperature stress treatment of freshly isolated microspores, achieving a high percentage of haploid embryos $(1,6)$. However, one of the limiting factors of embryogenesis induction and early embryogenic development is the fact that after the stress treatment some microspores do not respond to the induction and die, reducing microspore embryogenesis efficiency (8-11).

Cell viability is one of the determinant factors through stress response, and implies activation of various signal cascades to promote a switch towards embryogenesis induction (4). Different cell-death pathways control specific developmental processes to eliminate damaged or no longer required cells. The programmed cell death (PCD) is an active controlled process, generally of selective advantage for the organism, that occurs during vegetative and reproductive development as well as in response to various biotic and abiotic stresses $(12,13)$. In plants, PCD is associated with a vacuolar type of cell death in which the cell contents are removed by a combination of autophagy process and release of proteases and hydrolases from lytic vacuoles (14). According to the current MEROPS classification, the cysteine-dependent protease clan (CD clan) contains the major cell-death proteases including caspases, metacaspases and paracaspases (C14 family), present in all taxonomic groups (15). The controlled death of cells in animals is operated by proteases known as caspases ('cysteine aspartic-specific proteases'), and their activation leads to irreversible proteolytic cascade, being the central core of the death machinery (12). Pioneering research on phylogenetic distribution of $\mathrm{C} 14$ family reported the conservation between animal and plant proteases that lead to the cleavage of target proteins for the execution of cell death $(16,17)$. Despite their key role in the regulation and execution of the death program, no caspase homologues have been found in plant genomes. Beside this, caspase-like enzymatic activity has been found to participate in plant specific developmental processes, for example the PCD of embryo suspensor in Picea abies (18), leaf morphogenesis of Aponogeton madagascariensis (19) or tapetum development in Nicotiana tabacum and Brassica napus (20), different plant systems undergoing cell death processes. Among caspase-like activities, caspases 1, 3 and 6-like enzymatic activities are the most abundant and active in plants, as occurs in the protease cascades triggered by animal caspases (21).
In this work, cell death levels have been analysed in microspore cultures of $B$. napus during the first stages after embryogenesis induction, as well as the involvement of caspase 3-like activity in cell death. The results showed high cell death levels at early stages of stress-induced microspore embryogenesis, probably triggered by the inductor stress treatment. Concomitantly, an increase of caspase 3-like activity was detected. Moreover, inhibition of these proteases with specific compounds in microspore cultures significantly reduced cell death levels indicating a role of caspase 3-like activity in microspore death.

\section{Materials and Methods}

\section{Plant material, growth conditions and in vitro microspore embryogenesis culture}

Brassica napus L. (rapeseed) cv. 'Topas' line DH407 plants were used as donor plants. Rapeseed seeds were germinated and grew under controlled conditions (relative humidity $60 \%, 15^{\circ} \mathrm{C}$ under long-day photoperiod $16 \mathrm{~h}$ light and $8 \mathrm{~h}$ dark at $10^{\circ} \mathrm{C}$ ) in a growth chamber (Sanyo MLR-351-H) in pots containing a mixture of organic substrate and vermiculite $(2 / 1, \mathrm{v} / \mathrm{v})$.

Flower buds containing vacuolated microspores, the most responsive stage for microspore induction, were isolated for microspore culture. After isolation, microspore cultures were subjected to an in vitro stress treatment of $32^{\circ} \mathrm{C}$ as previously described (6), to induce embryogenesis.

\section{Fixation and staining techniques for microscopic analysis}

Samples of microspore cultures were fixed in $4 \%$ paraformaldehyde in phosphate-buffered saline (PBS), $\mathrm{pH}$ 6.8, overnight at $4^{\circ} \mathrm{C}$. They were dehydrated in acetone series, embedded in Technovit 8100 resin (Kulzer, Germany) at $4^{\circ} \mathrm{C}$ and sectioned at $2 \mu \mathrm{m}$ thickness using an ultramicrotome (Ultracut E Reichert) as previously described (22). Semi-thin sections were stained with $1 \%$ toluidine blue, for structural analysis, mounted with Eukitt and observed under bright field microscopy.

\section{Cell death detection}

Microspore culture samples were incubated with $0.25 \%(\mathrm{w} / \mathrm{v})$ Evans blue aqueous solution for $45 \mathrm{~min}$ at $4^{\circ} \mathrm{C}$ as previously described (23). The proportion of the dead cells (stained ones) were quantified under bright light with an optic microscope Leitz Laborlux 12. The average of percentage of dead cells was obtained by three independent experiments with two technical replicates. A minimum of 2,000 cells were counted per replicate.

\section{Caspase 3 activity assay}

Total proteins were extracted from in vitro samples grounded in extraction buffer (50 mM HEPES pH 7.4, 5 mM CHAPS, 5 mM DTT), and protein concentration was determined by Bradford method, using the Bio-Rad Protein Assay (Quick-Start Bradford Dye Reagent, Bio-Rad Hercules, CA, United States). Caspase 3-like enzymatic activity was performed as previously described (9), using the Caspase 3 Assay Kit, Colorimetric (CASP3C, Sigma Aldrich), which is based on the hydrolysis of 


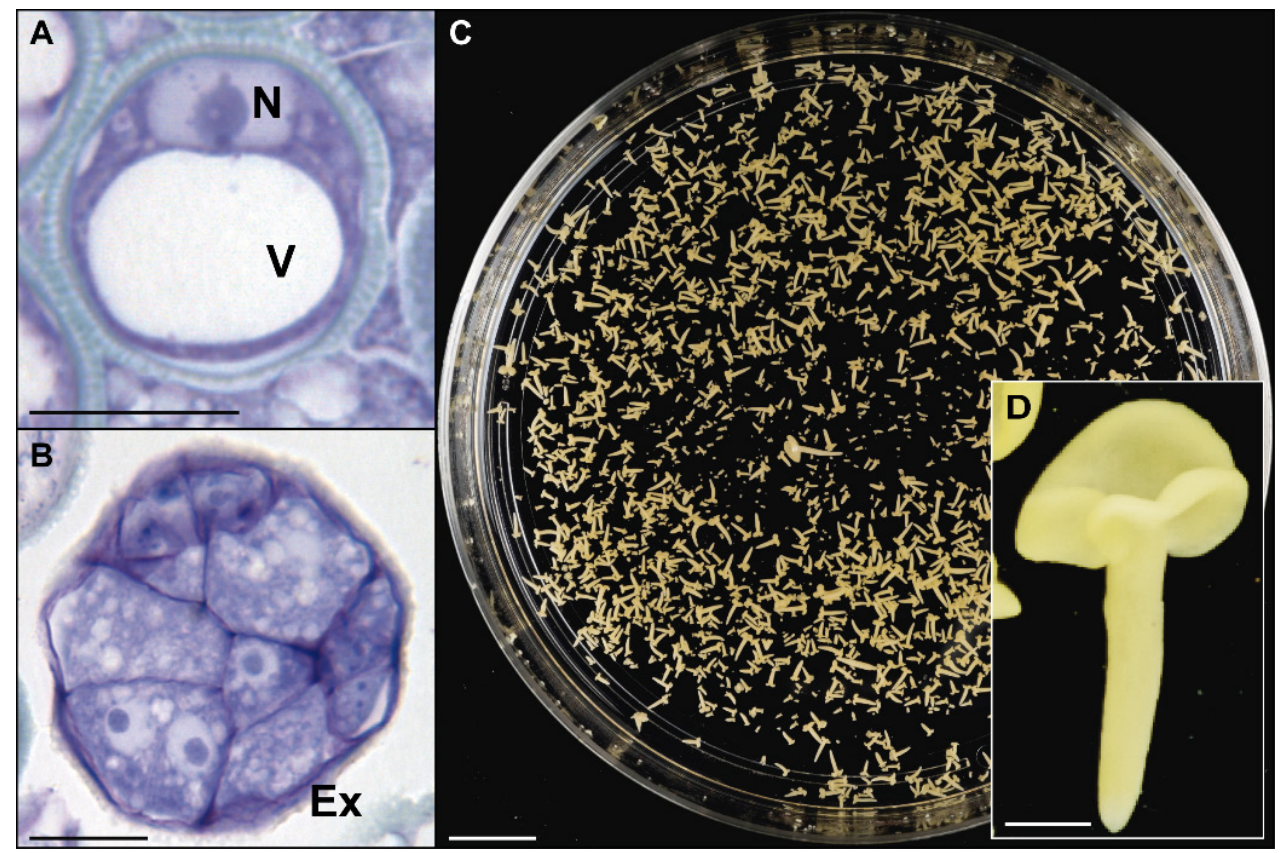

Figure 1. Main stages of stress-induced microspore embryogenesis in Brassica napus. Micrographs of toluidine blue-stained sections, for cell structure analysis in (A) isolated vacuolated microspore at culture initiation and (B) proembryo, formed in microspore culture, 4 days after stress, still surrounded by the exine (Ex). (C) Panoramic view of microspore-derived cotyledonary embryos, in the Petri dish. (D) Higher magnification view, showing a detail of a fully differentiated cotyledonary embryo. V: vacuole; N: nucleus; Ex: exine. Scale bars: (A-B) $5 \mu \mathrm{m}$; (C) $1 \mathrm{~cm}$; (D) $1 \mathrm{~mm}$.

the peptide substrate acetyl-Asp-Glu-Val-Asp p-nitroanilide (Ac-DEVD-pNA) moiety in the presence or absence of $20 \mu \mathrm{M}$ caspase 3 inhibitor (Ac-DEVD-CHO). The reaction was incubated at $37^{\circ} \mathrm{C}$ for $3 \mathrm{~h}$ and accumulation of pNA was detected at $405 \mathrm{~nm}$ and converted into $\mu \mathrm{mol}$ of pNA released per minute and milligram of protein extract. All assays were performed on three independent samples, measured in duplicate, and $p$-values were calculated using the Student $t$-test.

\section{Treatment with caspase 3 inhibitor}

The caspase 3 specific inhibitor acetyl-Asp-Glu-Val-Asp-aldehyde (Ac-DEVD-CHO) was added to the culture plates at the initiation of microspore cultures. A stock solution of $10 \mathrm{mM}$ Ac-DEVD-CHO was dissolved in dimethylsulfoxide (DMSO) and used at concentrations $5 \mu \mathrm{M}$ and $20 \mu \mathrm{M}$, keeping parallel control plates with DMSO.

Embryogenesis induction was quantified in control and AcDEVD-CHO-treated cultures by the number of proembryos formed after inductor stress. Mean percentages were obtained from three independent experiments with two replicates, as previously described (24).

\section{Statistical analysis}

All data presented were means from at least three independent experiments and were represented as mean \pm S.E.M. Comparison between means of isolated microspore (before stress) and stress-treated microspores was made with Student's $t$-test $(p<$ 0.05). Effects of Ac-DEVD-CHO on cell death and embryogenesis induction were assessed by analysis of variance (ANOVA) followed by the Tukey test to determined significance $(p<0.05)$.

\section{Results and Discussion}

Cell death increases by the inductor stress to trigger microspore embryogenesis

After culture of isolated vacuolated microspores (Fig. 1.A), the most responsive developmental stage for microspore embryogenesis, suspension cultures were subjected to an in vitro stress treatment of $32^{\circ} \mathrm{C}$, as previously reported (6). After 24$48 \mathrm{~h}$ under these conditions, responsive microspores were reprogrammed, switched its normal development and initiated an embryogenic pathway where active proliferation produced multicellular structures, still surrounded by the microspore wall (the exine), named "proembryos" (Fig. 1.B), clearly observed after 4 days at culture. At the same time, some microspores did not respond to reprogramming and either stopped development or died (8). As embryogenesis progressed, in the following days of culture, continuous cell division occurred, the exine was broken, and finally, differentiated embryos developed (Fig. 1.C) following a zygotic embryogenesis-like pathway of a dicot plant, through globular, heart, torpedo and cotyledonary (Fig. 1.D) embryo stages.

Recent studies have reported several determinant cellular and molecular factors that underlie stress-induced microspore embryogenesis and promote the switch towards a totipotent state. Among these factors, hormonal control, cytoskeletal rearrangement, chromatin and epigenetic modifications or cell wall remodelling are the most important $(11,22,24,25,26)$. Moreover, autophagy and cell death have been reported as crucial events that are activated in the stress response of microspores at early microspore embryogenesis in barley (10). 


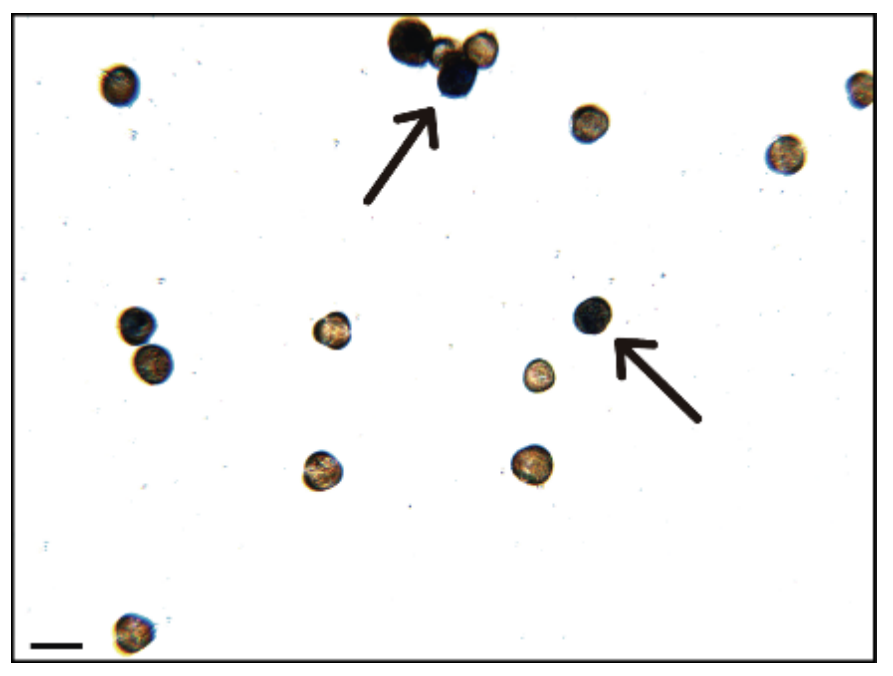

Figure 2. Detection of cell death in microspore culture, before stress. Representative micrograph of dead microspores revealed by Evans blue staining in isolated microspore culture, before the inductor stress. Arrows: dead cells. Scale bars: $10 \mu \mathrm{m}$.

In the present work, to study the cell death during microspore embryogenesis induction, two stages were analysed: "isolated microspores" (after isolation from flower buds and before the inductor stress, $0 \mathrm{~d}$ of culture), and "stress-treated microspores" (after the stress treatment, 4 days of culture). After microspore isolation, Evans blue technique, which selectively stains dead cells, showed the occurrence of cell death (Fig. 2), probably as a consequence of the isolation procedure. After the stress treatment, there was an increase in the number of dead cells, while responsive microspores co-existed with death microspores in microspore cultures.

The quantification of cell death levels showed a marked increase in cell death proportion after stress treatment (63.17 \pm $0.81 \%)$ in comparison with isolated microspores before the stress $(51.23 \pm 1.88 \%$ ) (Fig. 3). It should be further noted that reprogrammed embryogenic microspores represent only a fraction of microspores collected for culture. At least, 50\% of microspores collected through isolation from buds may be damaged, losing their embryogenic potential. In addition, after the response to inductor stress treatment, some microspores are able to reprogram initiating an embryogenic pathway, but a huge percentage of them are non-responsive microspores or dead ones, yielding low rates of embryogenesis efficiency $(9,10)$. Previous studies in barley microspore embryogenesis also indicate the existence of an oxidative unbalance that generate high levels of reactive oxygen species (ROS) in stress-treated microspores, a regular secondary stress responsible for antioxidant enzymes induction $(10,27)$.

Proteases with caspase 3-like activity are induced by the stress treatment triggering microspore embryogenesis

As caspases are main regulators and executioners of different cell-death programmes in animals and caspase-like activity has been detected in plant specific developmental processes (18-
Cell death

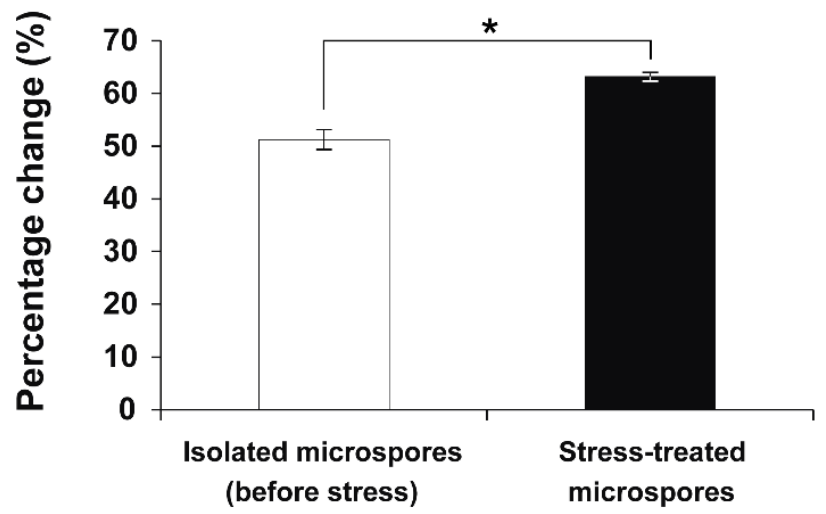

Figure 3. Cell death quantification in stress-induced microspore embryogenesis in B. napus. Histogram showing the percentage of dead cells identified by Evans blue staining before and after stress treatment. Columns represent mean \pm S.E.M; Asterisk indicate significant differences (Student's $t$-test at $p<0.05$ ).

20), we have analysed if proteases with caspase 3-like activity were involved in stress-induced cell death of early microspore embryogenesis.

Caspase 3-like activity was analysed during early stages of microspore embryogenesis induction in $B$. napus through an enzymatic in vitro assay with the caspase 3-specifc substrate AcDEVD-pNA. The results showed very low activity $(0.18 \pm 0.06$ $\mu \mathrm{mol}$ pNA $\left.\mathrm{min}^{-1} \mathrm{mg}^{-1}\right)$ at initial stage, in microspores before the inductor stress, whereas it greatly increased $(1.28 \pm 0.13 \mu \mathrm{mol}$ pNA min ${ }^{-1} \mathrm{mg}^{-1}$ ) in stress-treated microspores (Fig. 4). Controls with the caspase-specific inhibitor Ac-DEVD-CHO readily inhibited proteolytic activity of caspase 3 in both stages analysed of $B$. napus microspore embryogenesis, supporting the specificity of the enzymatic assay.

Despite a lack of close plant homologs of metazoan caspases, the possibility that plants have acquired proteases with caspaselike functions during specific developmental cell death processes still remains an open question. Two decades ago, Uren et al., (28) identified in silico an ancient family of caspase-like proteins in plants, fungi and protozoa, designed metacaspases. The growing evidence for caspase-related proteins (metacaspases) as key component of programmed cell death draw the attention to cell death researchers; being metacaspases reported during plant PCD processes in i.e. embryo suspensor in P. abies or xylem vessel elements in A. thaliana (29-31). Besides this, metacaspases and caspases have different substrate specificity, the chief property for correct measurement of its catalytic activity $(32,33)$; hence, metacaspases are not responsible for the observed caspase-like activities. In a previous report, we have shown an increase of caspase 3-like proteolytic activity after the inductor cold stress to trigger microspore embryogenesis in barley, a monocot plant (9). Here, we report additional evidence of caspase-like activity in a microspore embryogenesis system induced by heat stress in a dicot plant, suggesting a con- 
Caspase 3-like activity

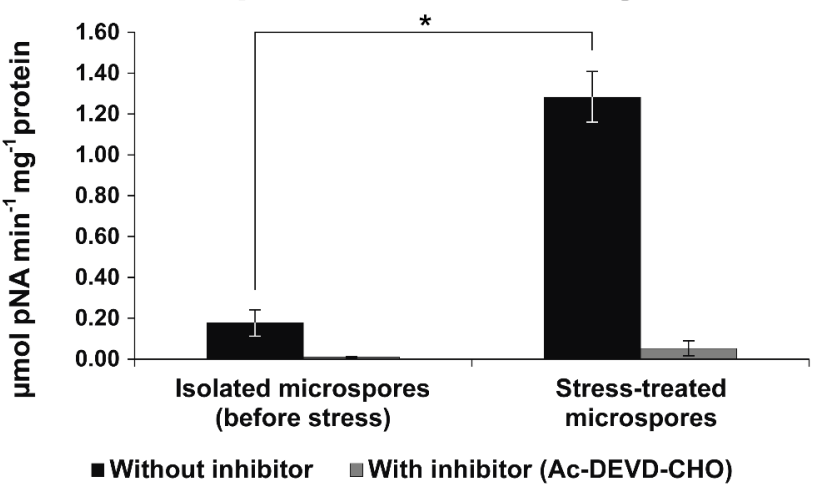

Figure 4. Caspase 3-like activity in microspore cultures in $B$. napus. Histogram showing caspase 3-like activity (black columns) and negative controls with the caspase 3 inhibitor (grey columns) before and after stress treatment. Columns represent mean \pm S.E.M. Asterisk indicate significant differences (Student's $t$-test at $p<0.05)$.

served molecular function of proteases with caspase-like activity in specific developmental processes of stress-induced cell death, as previously reported in others plant systems exposed to abiotic stresses such as UV-C, oxidative stress $\left(\mathrm{H}_{2} \mathrm{O}_{2}\right.$, methyl viologen) and endoplasmic reticulum stress $(34,35)$. The present results have also shown that the increase of cell death levels after the inductor stress was accompanied by an increase of caspase 3-like activity.

\section{Proteases with caspase 3-like activity are involved in} stress-induced cell death of microspore embryogenesis To evaluate if the proteolytic activity of caspase 3 -like has a role in stress-induced cell death of microspore cultures, we performed in vitro treatments of microspore cultures with a caspase 3 inhibitor Ac-DEVD-CHO, a synthetic tetrapeptide which has been reported to inhibit animal caspase 3 protease by specific competitive manner (16). At the initiation of the microspore cultures, Ac-DEVD-CHO was added to microspores plates at different concentrations ( $5 \mu \mathrm{M}$ and $20 \mu \mathrm{M}$ ), keeping parallel culture plates without the inhibitor, and the effects on cell death was monitored at early stage of microspore induction, after the stress. The results of the quantification of cell death levels revealed that mean percentage of dead cells in microspore cultures treated with AcDEVD-CHO was statistically significant lower than control cultures, with the two concentrations used (Fig. 5).

It has been described using synthetic tetrapeptide substrates/ inhibitors that plant proteases with caspase 3-like activity participate in many PCD processes (36). In support of this, Bárány et al., (10) have shown that cell death was connected to caspase 3-like proteolytic activity in microspore embryogenesis induced by cold stress in $H$. vulgare. On the other hand, proteases are known to be crucial and associated with cell death and survival in plant immunity- and biotic stress-related PCD processes. Within proteases, caspase 3-like DEVDase activity mediated plant immunity against bacterial pathogens in A. thaliana $(37,38)$.

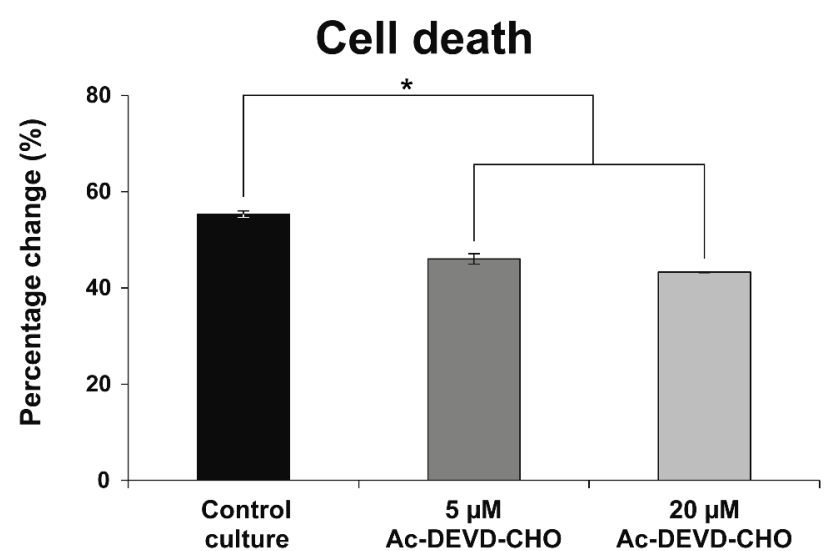

Figure 5. Quantification of cell death levels in control and AcDEVD-CHO-treated microspore cultures. Histogram showing the percentage of dead cells identified by Evans blue staining in control and Ac-DEVD-CHO-treated cultures, 4 days after stress. Columns represent mean \pm S.E.M; Asterisk indicate significant differences (ANOVA and Tukey's test at $p<0.05$ ).

Nevertheless, less is known about cell death processes and the participation of caspase-like activities in response to moderate abiotic stress treatment in plant cell suspension cultures $(9,10,39)$. Our results showed that Ac-DEVD-CHO treatment (specific caspase 3 inhibitor) reduced cell death proportion in a concentration-dependent fashion. This fact provides additional evidence for the connection of caspase-like activity to cell death after stress treatment triggering microspore embryogenesis, but functional evidence for its contribution to cell death remains to be fully demonstrated.

\section{Inhibition of caspase 3-like activity enhances microspore embryogenesis initiation}

The effect of the treatment with caspase 3-like inhibitor on embryogenesis induction was also evaluated. Proembryos formed after the inductor stress, the first signal and particular marker of microspore embryogenesis induction, could be clearly distinguished from the non-responsive microspores present in the culture because of the morphological characteristics of proembryos; they were rounded and larger structures displaying higher density than the microspores, under bright field microscopy (Fig. 6). Proembryos were more numerous in microspore cultures treated with the Ac-DEVD-CHO inhibitor (Fig. 6B), in comparison with control cultures (Fig. 6A). In addition, at the same culture time point, some proembryos of Ac-DEVD-CHO-treated cultures exhibited higher size than those of control cultures; as a matter of fact they showed the breakdown of exine wall (Fig. 6B, arrowhead).

The effect of caspase 3-like inhibitor on embryogenesis induction was also quantified at the same culture time point in untreated and treated microspore cultures. The results indicated a significant increase in the percentage of proembryos and therefore in the embryogenesis induction rate in those microspore cultures treated with caspase 3-like inhibitor, compared with untreated cultures (Fig. 7). 


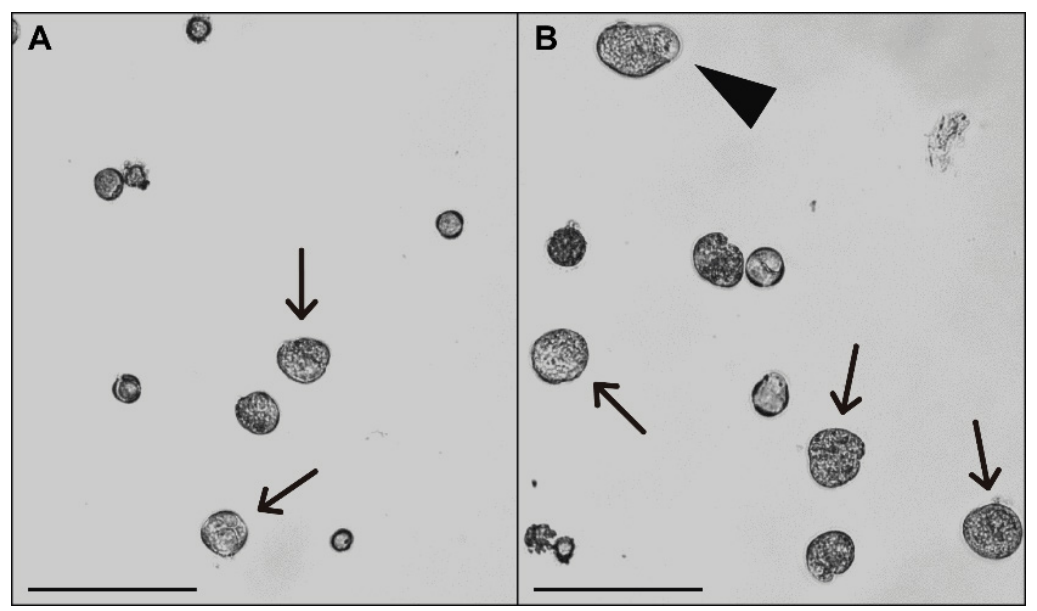

Figure 6. Effects of Ac-DEVD-CHO on microspore embryogenesis induction. Representative micrographs of microspore cultures showing proembryos formed (pointed by arrows) in (A) control cultures and (B) Ac-DEVD-CHO-treated cultures, 4 days after stress. Arrowhead: proembryo with the breakdown of exine wall. Scale bars: $50 \mu \mathrm{m}$.

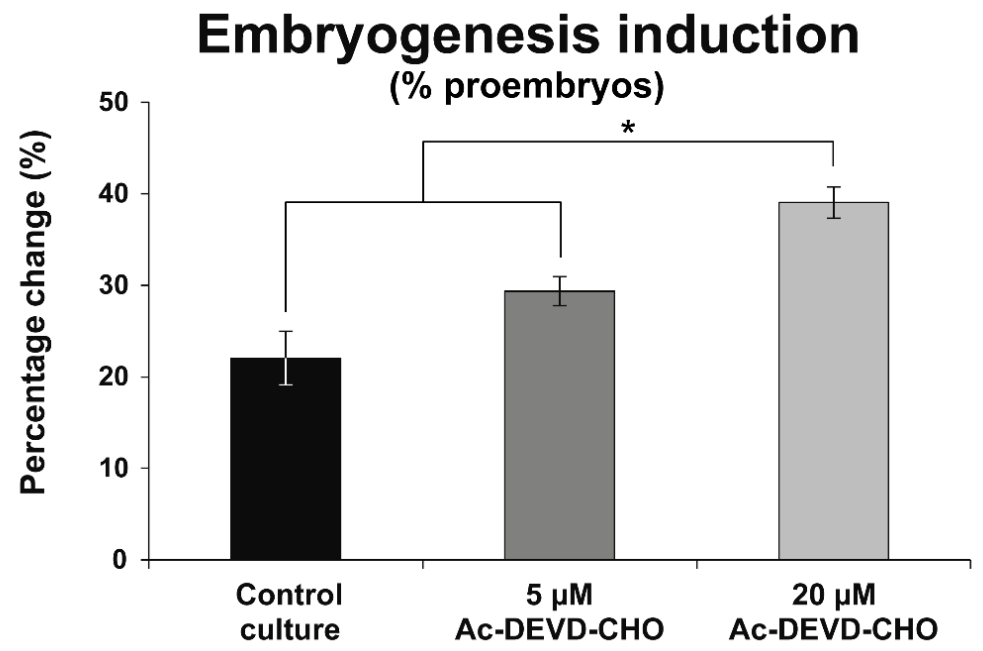

Figure 7. Quantification of embryogenesis induction levels in control and Ac-DEVD-CHO-treated microspore cultures. Histogram showing the percentage of proembryos formed in control and Ac-DEVD-CHO-treated cultures, 4 days after stress. Columns represent mean \pm S.E.M; Asterisk indicate significant differences (ANOVA and Tukey's test at $p<0.05$ ).

Despite the efforts of the last years, the complex regulatory network for cellular reprogramming leading to embryogenesis induction is still far to be fully elucidated. Therefore, the characterization of processes limiting its efficiency, such as cell death and protease activities, which are induced in response to the inductor stress to trigger embryogenesis, could help to design biotechnological strategies to improve the process. The results presented here show an increase of microspore embryogenesis initiation using a caspase 3-like inhibitor, opening up new possibilities to enhance microspore embryogenesis yield in important plant crops, with recalcitrant response.

\section{Conclusions}

In summary, one of the major factors that reduces efficiency in stress-induced microspore embryogenesis is cell death occurrence after stress treatment. In addition, proteases with caspase 3-like activity are induced together with stress-induced cell death in microspore embryogenesis, and its inhibition by Ac-DEVD-CHO reduces cell death levels and improves embryogenesis yield, as a consequence of this reduction. These findings indicate a role of caspase 3-like proteolytic activity in cell death execution of microspores. Approaches with pharmacological treatments using caspase 3-like inhibitors or celldeath protease modulators can enhance microspore embryogenesis yield, opening fields for further improvement with new biotechnological strategies that can be applied in recalcitrant species to improve microspore embryogenesis systems, for application in crop breeding programmes.

\section{Acknowledgements}

Work supported by projects (AGL2014-52028-R and AGL201782447-R) funded by the National Agency of Research (AEI) of Spanish Ministry of Science and Universities (MCIU) and the European Regional Development Fund (ERDF/FEDER). 


\section{Conflict of Interest}

Authors declare that they have no competing interest.

\section{Ethical Compliance}

This article does not contain any studies involving human participants or animals performed by any of the authors.

\section{References}

1. Maluszynski M, Kasha K, Forster BP, Szarejko I, editors. Doubled haploid production in crop plants: a manual. Springer Science \& Business Media; 2013.

2. Ferrie AM, Caswell KL. Isolated microspore culture techniques and recent progress for haploid and doubled haploid plant production. Plant Cell, Tissue and Organ Culture (PCTOC). 2011; 104(3): 301-9.

3. Testillano PS. Microspore embryogenesis: targeting the determinant factors of stress-induced cell reprogramming for crop improvement. Journal of Experimental Botany. 2019; 70(11): 296578.

4. Germana MA, Lambardi $M$, editors. In vitro embryogenesis in higher plants. Humana Press; 2016.

5. Bárány I, González-Melendi P, Fadón B, Mitykó J, Risueño MC, Testillano PS. Microspore-derived embryogenesis in pepper (Capsicum annuum L.): subcellular rearrangements through development. Biology of the Cell. 2005; 97(9): 709-22.

6. Prem D, Solís MT, Bárány I, Rodríguez-Sanz H, Risueño MC, Testillano PS. A new microspore embryogenesis system under low temperature which mimics zygotic embryogenesis initials, expresses auxin and efficiently regenerates doubled-haploid plants in Brassica napus. BMC Plant Biology. 2012; 12(1): 127.

7. Shariatpanahi ME, Belogradova K, Hessamvaziri L, Heberle-Bors $\mathrm{E}$, Touraev A. Efficient embryogenesis and regeneration in freshly isolated and cultured wheat (Triticum aestivum L.) microspores without stress pretreatment. Plant Cell Reports. 2006; 25(12): 1294-9.

8. Satpute GK, Long H, Seguí-Simarro JM, Risueño MC, Testillano PS. Cell architecture during gametophytic and embryogenic microspore development in Brassica napus L. Acta Physiologiae Plantarum. $2005 ; 27(4)$ : 665-74.

9. Rodríguez-Serrano M, Bárány I, Prem D, Coronado MJ, Risueño MC, Testillano PS. NO, ROS, and cell death associated with caspase-like activity increase in stress-induced microspore embryogenesis of barley. Journal of Experimental Botany. 2011; 63(5): 2007-24.

10. Bárány I, Berenguer E, Solís MT, Pérez-Pérez Y, Santamaría ME, Crespo JL, Risueño MC, Díaz I, Testillano PS. Autophagy is activated and involved in cell death with participation of cathepsins during stress-induced microspore embryogenesis in barley. Journal of Experimental Botany. 2018; 69(6): 1387-402.

11. Pérez-Pérez $Y$, Carneros $E$, Berenguer E, Solís MT, Bárány I, Pintos B, Gómez-Garay A, Risueño MC, Testillano PS. Pectin de-methylesterification and AGP increase promote cell wall remodeling and are required during somatic embryogenesis of Quercus suber. Frontiers in Plant Science. 2019; 9: 1915.

12. Daneva A, Gao Z, Van Durme M, Nowack MK. Functions and regulation of programmed cell death in plant development. Annual Review of Cell and Developmental Biology. 2016; 32: 441-68.

13. Huysmans M, Lema S, Coll NS, Nowack MK. Dying two deaths programmed cell death regulation in development and disease. Current Opinion in Plant Biology. 2017; 35: 37-44.

14. Van Doorn WG, Beers EP, Dangl JL, Franklin-Tong VE, Gallois $P$, Hara-Nishimura I, Jones AM, Kawai-Yamada M, Lam E, Mundy J, Mur LA. Morphological classification of plant cell deaths. Cell Death and Differentiation. 2011; 18(8): 1241.
15. Minina EA, Coll NS, Tuominen H, Bozhkov PV. Metacaspases versus caspases in development and cell fate regulation. Cell Death and Differentiation. 2017; 24(8): 1314.

16. Poręba M, Stróżyk A, Salvesen GS, Drąg M. Caspase substrates and inhibitors. Cold Spring Harbor Perspectives in Biology. 2013; 5(8): a008680.

17. Buono RA, Hudecek R, Nowack MK. Plant proteases during developmental programmed cell death. Journal of Experimental Botany. 2019; 70(7): 2097-112.

18. Bozhkov PV, Filonova LH, Suarez MF, Helmersson A, Smertenko AP, Zhivotovsky B, Von Arnold S. VEIDase is a principal caspase-like activity involved in plant programmed cell death and essential for embryonic pattern formation. Cell Death and Differentiation. 2004; 11(2): 175.

19. Gunawardena AH, Greenwood JS, Dengler NG. Programmed cell death remodels lace plant leaf shape during development. The Plant Cell. 2004; 16(1): 60-73.

20. Solís MT, Chakrabarti N, Corredor E, Cortés-Eslava J, Rodríguez-Serrano $M$, Biggiogera M, Risueño MC, Testillano PS. Epigenetic changes accompany developmental programmed cell death in tapetum cells. Plant and Cell Physiology. 2013; 55(1): 16-29.

21. Van Durme M, Nowack MK. Mechanisms of developmentally controlled cell death in plants. Current Opinion in Plant Biology. 2016; 29: 29-37.

22. Solís MT, Berenguer E, Risueño MC, Testillano PS. BnPME is progressively induced after microspore reprogramming to embryogenesis, correlating with pectin de-esterification and cell differentiation in Brassica napus. BMC Plant Biology. 2016; 16(1): 176.

23. Solís MT, El-Tantawy AA, Cano V, Risueño MC, Testillano PS. 5-azacytidine promotes microspore embryogenesis initiation by decreasing global DNA methylation, but prevents subsequent embryo development in rapeseed and barley. Frontiers in Plant Science. 2015; 6: 472.

24. Berenguer E, Bárány I, Solís MT, Pérez-Pérez Y, Risueño MC, Testillano PS. Inhibition of histone H3K9 methylation by BIX-01294 promotes stress-induced microspore totipotency and enhances embryogenesis initiation. Frontiers in Plant Science. 2017; 8: 1161.

25. Gervais C, Newcomb W, Simmonds DH. Rearrangement of the actin filament and microtubule cytoskeleton during induction of microspore embryogenesis in Brassica napus L. Cv. Topas. Protoplasma. 2000; 213(3-4): 194-202.

26. Rodríguez-Sanz H, Solís MT, López MF, Gómez-Cadenas A, Risueño MC, Testillano PS. Auxin biosynthesis, accumulation, action and transport are involved in stress-induced microspore embryogenesis initiation and progression in Brassica napus. Plant and Cell Physiology. 2015; 56(7): 1401-17.

27. Maraschin SD, Caspers M, Potokina E, Wülfert F, Graner A, Spaink HP, Wang M. CDNA array analysis of stress-induced gene expression in barley androgenesis. Physiologia Plantarum. 2006; 127(4): 535-50.

28. Uren AG, O'Rourke K, Aravind L, Pisabarro MT, Seshagiri S, Koonin EV, Dixit VM. Identification of paracaspases and metacaspases: two ancient families of caspase-like proteins, one of which plays a key role in MALT lymphoma. Molecular Cell. 2000; 6(4): 961-7.

29. Suarez MF, Filonova LH, Smertenko A, Savenkov El, Clapham DH, von Arnold S, Zhivotovsky B, Bozhkov PV. Metacaspase-dependent programmed cell death is essential for plant embryogenesis. Current Biology. 2004; 14(9): R339-40.

30. Bozhkov PV, Suarez MF, Filonova LH, Daniel G, Zamyatnin AA, Rodriguez-Nieto $S$, Zhivotovsky $B$, Smertenko A. Cysteine protease mcll-Pa executes programmed cell death during plant embryogenesis. Proceedings of the National Academy of Sciences. 2005; 102(40): 14463-8.

31. Bollhöner B, Zhang B, Stael S, Denancé N, Overmyer K, Goffner D, Van Breusegem F, Tuominen H. Post mortem function of AtMC9 in 
xylem vessel elements. New Phytologist. 2013; 200(2): 498-510.

32. Vercammen D, Van De Cotte B, De Jaeger G, Eeckhout D, Casteels P, Vandepoele K, Vandenberghe I, Van Beeumen J, Inzé D, Van Breusegem F. Type II metacaspases Atmc4 and Atmc9 of Arabidopsis thaliana cleave substrates after arginine and lysine. Journal of Biological Chemistry. 2004; 279(44): 45329-36.

33. Tsiatsiani L, Van Breusegem F, Gallois P, Zavialov A, Lam E, Bozhkov PV. Metacaspases. Cell Death and Differentiation. 2011; 18(8): 1279.

34. Danon A, Rotari VI, Gordon A, Mailhac N, Gallois P. Ultraviolet-C overexposure induces programmed cell death in Arabidopsis, which is mediated by caspase-like activities and which can be suppressed by caspase inhibitors, p35 and Defender against Apoptotic Death. Journal of Biological Chemistry. 2004; 279(1): 77987.
35. Ge Y, Cai YM, Bonneau L, Rotari V, Danon A, McKenzie EA, McLellan $\mathrm{H}$, Mach L, Gallois P. Inhibition of cathepsin B by caspase-3 inhibitors blocks programmed cell death in Arabidopsis. Cell Death and Differentiation. 2016; 23(9): 1493.

36. Bonneau L, Ge Y, Drury GE, Gallois P. What happened to plant caspases?. Journal of Experimental Botany. 2008; 59(3): 491-9.

37. Hatsugai N, Iwasaki S, Tamura K, Kondo M, Fuji K, Ogasawara K, Nishimura M, Hara-Nishimura I. A novel membrane fusion-mediated plant immunity against bacterial pathogens. Genes \& Development. 2009; 23(21): 2496-506.

38. Balakireva A, Zamyatnin A. Indispensable role of proteases in plant innate immunity. International Journal of Molecular Sciences. $2018 ; 19(2): 629$.

39. Reape TJ, McCabe PF. Apoptotic-like regulation of programmed cell death in plants. Apoptosis. 2010; 15(3): 249-56. 